\title{
Service to Human Beings is Service to God: A General Concern for Humanity
}

\author{
Philip Quacoe-Takrama ${ }^{1}$ \\ 1 Sefwi-Wiawso College of Education, Department of Social Science, Sefwi-Wiawso, Ghana.
}

\begin{abstract}
No leader can lead without serving; a leader must be humble and ready to bring to bear that attitude through service to others. It is also necessary for a leader to make his or her service to people a private affair. Hence service is not to be rendered for rewards because service must go unrewarded by people if it is to meet the Master's standard. What is needed of humanity today, is the need to serve one another rather than looking for assistance from others. This is a theological reflection, leaning towards service to God which invariably comes through service to human beings. Humanity is today bedeviled with eye service leaders, who serve with the intent to make profit and with the mindset of gaining popularity. Many quickly seize ministry opportunities when the ministry is prominent, proving, popular, prestigious, fulfilling, and profitable but shy away if the opposite is the case. This paper posits that service in any capacity to people is regarded as service unto the Lord. Its stance is that the act of service is the sure way to go if the service of people is to make a meaningful and lasting impact on humanity.
\end{abstract}

Correspondence

Philip Quacoe-Takrama

Email: philipquacoe49@gmail.com

Publication History

Received 19th January 2021,

Accepted 19th March 2021,

Published online 30th March 2021.

Keywords: Service, Humanity, God.

\section{INTRODUCTION}

John 13:1 Now before the feast of the passover, when Jesus knew that his hour was come that he should depart out of this world unto the Father, having loved his own which were in the world, he loved them unto the end.13:2 And supper being ended, the devil having now put into the heart of Judas Iscariot, Simon's son, to betray him;13:3 Jesus knowing that the Father had given all things into his hands, and that he was come from God, and went to God;13:4 He riseth from supper, and laid aside his garments; and took a towel, and girded himself.13:5 After that he poureth water into a bason, and began to wash the disciples' feet, and to wipe them with the towel wherewith he was girded.13:6 Then cometh he to Simon Peter: and Peter saith unto him, Lord, dost thou wash my feet?13:7 Jesus answered and said unto him, What I do thou knowest not now; but thou shalt know hereafter.13:8 Peter saith unto him, Thou shalt never wash my feet. Jesus answered him, If I wash thee not, thou hast no part with me.13:9 Simon Peter saith unto him, Lord, not my feet only, but also my hands and my head.13:10 Jesus saith to him, He that is washed needeth not save to wash his feet, but is clean every whit: and ye are clean, but not all.13:11 For he knew who should betray him; therefore said he, Ye are not all clean.13:12 So after he had washed their feet, and had taken his garments, and was set down again, he said unto them, Know ye what I have done to you?13:13 Ye call me Master and Lord: and ye say well; for so I am.13:14 If I then, your Lord and Master, have washed your feet; ye also ought to wash one another's feet.13:15 For I have given you an example, that ye should do as I have done to you.13:16 Verily, verily, I say unto you, The servant is not greater than his lord; neither he that is sent greater than he that sent him.13:17 If ye know these things, happy are ye if ye do them (KJV).

The text in the book of John 13:1-17 will be the focus of this paper. A random selection of verses has been made to enhance the discussion. The emphasis of this work is Jesus washing his disciples' feet in John 13 and how leaders of today can emulate the actions of Jesus in their day-to-day living. The character quality of service in leadership otherwise demonstrated and encouraged by Jesus is indispensable in the journey of Christian leadership as well as in secular leadership. The role of service in leadership, the royalty of service, and integrity among others will be the basics of the 
discussion. The feet-washing event organized by Jesus began with Jesus assuming the role of a servant (v.4 of John 13) when he disrobed and donned on a towel. The description of both the preparations and the execution of the act (v. 5) bear close comparison with John 12:3. Feet washing was a common practice in Jewish households (e.g. Luke 7:44), and Jewish servants could even refuse to perform the task as it was too menial. It was, however, sometimes performed by the guests themselves or on occasions by disciples in honor of their master. Peter however interrupted the feet-washing session (v. 6) because he was incredulous at Jesus performing an act that was regarded as menial. Jesus' reply (v. 7) both underlines the motif of the disciples' misunderstanding which Peter typifies and serves to point forward to the event's significance as an act of cleansing for Peter's later denial of Jesus. These are the elements that characterized the Lord's washing of the Disciples' feet.

The Lord's washing of the disciples' feet was an act of service; it was a necessary and beneficial service; this was not "busy work". It was not a work for work's sake, but work that had practical benefits for the disciples' clean feet. The Lord's washing of his disciples' feet was menial service. Feet washing was considered as 'dirty work,' work because it required the Lord to "get His hands dirty". This work was so menial that the disciples were not willing to do it themselves, and at least Peter attempted to keep Jesus from carrying out this humble task. The Lord's service of washing the disciples' feet was a voluntary act, motivated by love. Jesus was not fulfilling any Old Testament Prophecy; what Jesus chose to do here was not "His job description." The Lord's service was "above and beyond the call of duty". This without a doubt is the general concern of humanity, to engage in service to people, not for eye service but out of love. This is the focus of this paper.

\section{The role of Service in leadership}

(Vv. 15-17). "For I have given you, an example that you should do as I have done to you. Verily, verily, I say unto you, the servant is not greater than his Lord, neither he that is sent greater than he that sent him. If ye know these things, happy (blessed) are ye if ye do them."

According to this passage being humble must be consummated in service to attract the blessing upon the servant leader. The opportunity to serve may not be attractive or acknowledged by people but in the eyes of the Lord, servant leaders have to seize the moment and serve faithfully. The blessing of service comes from God. Wiersbe notes that servants "do not look for a big opportunity, worthy of their abilities. Those will come in due time."' The great saints of the Bible started as servants, not rulers, and they were faithful over a few things before God made them rulers. Moses tended sheep; Joseph was a carpenter. Human beings are therefore entreated to live under the direction of God and to eschew the praises of men. It is also important to serve faithfully away from the pubic eye which will result in God's approval at the end. Every service opportunity is an opportunity to exercise sovereignty in Christ. Human beings, therefore, reign in life by loving to serve, to the glory of God. ${ }^{2}$ This is an act of true servant leadership that Jesus admonished his disciples to portray.

\section{The Royalty of Service}

Verses 3 and 5 "He had come from God and was going to God ... He poured water into a basin and began to wash the disciples'feet, and to wipe them with his own towel, with which he was girded."

Looking at this aspect closely, there appear to be few incidents in the Gospel story that reveals the character of Jesus which perfectly emulates His love. It is when one thinks of what Jesus might have been and what he might have done that the supreme wonder of his actions becomes evident. As servant leaders, service must be the expression of a leadership style. As I Pet. 2:21 says, "For even hereunto were we called, because Christ also suffered for us, leaving us, an example, that we should follow his steps" (KJV). Barclay writes of St. Francis of Assisi, a shining example of a servant leader, who was quoted as saying, "it is not as we separate ourselves from men that we come near to God. The nearer we are to suffering humility, the nearer we are to God." ${ }^{\prime 3}$ Service, according to St. Francis, is the greatest proof of one's belief in God. And as it is, service to man is service to God. For faith without works is dead (Jam. 2:26). ${ }^{4}$ In v. 5 , Jesus is seen assuming the position of a servant, and washing the feet of his own disciples; the opposite should have been the case, but he decided to serve for that was the reason for his presence on earth. Collins observes that Jesus in the John narrative regarded the feet-washing as bringing into fulfillment Mark 10:43-45, which he had taught earlier by saying, "whoever wishes to be great among you, must become your servant...for the son of man came not to be served but to serve. ${ }^{5}$ Barrett also notes that "Jesus in full awareness of the situation, proceeded to perform the menial task of washing his disciples' feet." "Bruce et al. also insist that the necessity to wash the feet, was for comfort and cleanliness

\footnotetext{
Warren W. Wiersbe, Live like King: Living the Beatitudes Today, (Chicago: MoodyPress, 1980), 41.

Wiersbe, Live like King, 42.

William Barclay, The Gospel of John Vol. 2: XIII-XXI (Edinburgh: The Saint Andrew Press, 1961), 160.

Barclay, The Gospel of John Vol. 2, 160.

John N. Collins, Diakonia: Reinterpreting the Ancient sources (Oxford: Oxford University Press, 1990), 6.

Charles K. Barrett, Peake's Commentary of the Bible (London, Great Britain: Thomas Nelson Printers, 1967, 860.
} 
as a result of the dusty roads, and thus feet washing was a sign of hospitality, generally performed by the meanest slave, ${ }^{7}$ and yet Jesus did that with the greatest of ease. Hastings also agrees with the observation Bruce et al. made, saying, 'washing the feet stained with the dust of the road, was part of the regular duty of hospitality. The washing of the feet at the Last Supper is primarily connected with this custom in John 13. Christ the Lord and Master assumes the garb and does the work of a slave (13:4). ${ }^{8}$ As the v. 14 indicates "If I then your Lord and Master, have washed your feet, you also ought to wash one another's feet." Leaders of today must therefore be willing and ready to serve others as servant leaders of God. Barrett adds, 'Jesus' servants are not greater than him, yet conversely, as his envoys they truly represented him. ${ }^{9}$ What Jesus did for the disciples in v. 12 is explained in terms of an example given by Barret; "If he whom they acknowledge as 'Teacher' and 'Master' (revered terms) stooped to perform a slave's task for them, how much more readily should the disciples do the like for each other." ${ }^{10}$ The proud man looks for others to serve him. "Let each esteem the other than themselves" (Phil. 2:3). "By love serve one another" (Gal. 5:13). "Yea, and if I be offered upon the sacrifice and service of your faith, I joy and rejoice with you all." (Phil. 2: 17). Sacrifice and service are the twin children of humility. It is important to note that this sacrifice and service must go unnoticed and unrewarded. They have their reward; if leaders blow trumpets every time they help somebody, they will only nourish their pride and starve their humility. A cup of cold water for Jesus' sake is all that He asks. The sin of pride has ruined more lives than perhaps any other sin. Pride is the sin that invites Satan to rule. It is the sin that cost King Saul his character, the throne, his crown, and, ultimately, his life, humility is the grace that made David a king through service. ${ }^{11}$

No leader can lead without service; a servant leader must be one who is humble and ready to bring to bear that attitude through service to others. It is however necessary for the servant not to make his act of service announced or published for it must go unnoticed. Neither must service be rendered for rewards, for service must also be unrewarded if it is to meet the master's standard. Paul Super in Mott captured it this way, "One of my greatest resources these ten years in Poland is the sense of his backing. My great pride is his belief in me. Surely one of my greatest motives is to be worthy of his support and to measure up to his expectations of me. For the servant leader, his joy must be that his Lord believes in him and has His backing and support, not that of men." ${ }^{2}$ The servant must submit to God's training to enable him to be the servant leader God requires.

Hind wrote of Jesus "If there was one modern management trait that carried Jesus Christ from a nobody to a somebody, it was his service to and for the benefit of others. His servant leadership." ${ }^{13}$ Hind sees service as a modern management trait that perhaps both cooperate and church leadership must demonstrate as Jesus did if their lives are to be of benefit to those they lead and have influence over. This act of service is not acquired, it is learnt, and hence a period of training (at the feet of Christ) is required before a performance. Sanders wrote: "Jesus' teaching on servanthood and suffering was not intended merely to inspire good behavior. Jesus wanted to impart the spirit of servanthood, the sense of personal commitment and identity that he expressed when he said "I am among you as he who serves... (Luke 22: 27). John13: 13-14, states that mere acts of service could be performed with motives far from spiritual." ${ }^{14}$ Leaders can only serve better if they understudy Christ by submitting fully to his discipline to be imparted with the spirit of servanthood, in order that their act of service would not just be a mere show of outward religiosity, but a real spiritual act of service to God's glory.

\section{Comparative discussion of Service and Integrity today}

Richards and Hoeldtke write: "the New Testament's pictures of the servant as one who does, rather than one who adopts the leadership style of the world and tells, has unique integrity. The open life of leaders, among-not over-the brothers and sisters is a revelation of the very face of Jesus. And to see Jesus expressing himself in a human being brings the hope that transformation might be a possibility for me too." ${ }^{15}$ For a servant leader to do more service he has to learn more; learning enriches his service; the more one learns, the better service he or she is able to render. A leader who toys with knowledge cannot go far in his service to God and mankind; leaders can only reveal Christ to others if they are able to not only learn from him but to become like him on a daily basis. Cosgrove posits that "Leadership is service (servanthood). This teaching of leading by serving continues to have an unfamiliar ring in an age that calls mankind to achieve higher laurels in all its endeavours. ${ }^{16}$

The Bible teaches that to lead is to serve. One may recognize the truth of this concept and respond positively.

\footnotetext{
Frederick F. Bruce, James I. Packer, Randolph V. G. Tasker, Donald J. Wiseman Douglas The New Bible Dictionary. (London: Intervarsity Press), 434.

James Hastings, Dictionary of the Bible: Complete in one Volume (New York: Charles Scribner's Sons, 1952), 268.

Barrett, Peake's Commentary on the Bible, 860.

Barrett, Peake's Commentary on the Bible., 235-6.

Wiersbe, Live like King,41.

John R. Mott. Revival Fire (London: Hodder and Stoughton, 1990), 364.

James Hind, The Heart and Soul of Effective Management (Wheaton Illinois: Victors Press, 1989), 19.

Oswald J. Sanders, Spiritual Leadership: The Principle of Excellence for Every Believer (Chicago: Moody Press, 1994$), 23$.

Lawrence O. Richard, Clyde Hoeldtke, A Theology of Church Leadership (Grand Rapids: Zondervan Press, 1980), 120.

Francis Cosgrove, “The Disciple Is a Servant", Discipleship Journal 30, (1985): 35.
} 
The problem, however, is doing it consistently." ${ }^{17}$ Cosgrove's observation cannot be overemphasized because Christian leadership otherwise known as servant leadership is service and nothing but service contrary to the secular leadership style which is motivated by profit and self-interest, hence everything is done to climb to the top. It is this team of biblical leaders that are qualified to lead others. Kenneth and Gangel put it this way, "Biblical team leadership takes place when divinely appointed men and women accept responsibility for obedience to God's call... Above all, they exercise leadership as servants and stewards, sharing authority with their followers and affirming that leadership is primarily a ministry to others and mutual membership with others in Christ's body." ${ }^{18}$ Kenneth and Gangel put it straight, for nothing can be referred to as servant leadership, except when divinely appointed man and women accept the responsibility to God's call. Not only that but also he recognized the importance of preparation time, allowing the Holy Spirit to develop tenderness of hearts and skill of hands for quality service. This then gives them conviction, concerning their role to lead in the church." ${ }^{19}$ This is the only way leaders can model for others what ministry is primarily, which is service. "It is better we should always tackle something a bit beyond us.

We should always aim to read something different not only from the writers with whom we agree but those with whom we are ready to do battle and let us not condemn them out of hand because they do not agree with us. ${ }^{20} \mathrm{He}$ further insists, their viewpoint may not fully agree with other leaders' and may be totally different from others, yet servant leaders must be patient to learn from what they have written down. To be a good leader, one must be willing to be trained and learn from others and their experiences to build lasting integrity. This is how Thielkecke in an encounter with Spurgeon puts it "Master those books you have, read them thoroughly, bathe in them until they saturate. Read and reread them, masticate and digest them. Let them go into your very self. Peruse a good book several times and make notes and analyses of it... In reading, let your motto be much not many." ${ }^{21}$ The need to read wide about effective Christian service is necessary for every Christian leader that would influence others positively towards Christ-like service. Thielkecke is right in his observation that, when one good book is mastered very well, it benefits the individual far more than reading many without really being able to glean much from the pages. This motor for Christian leaders, which must be, much not many, must be the guiding principle for servant leaders.

\section{The way forward for contemporary leadership}

\section{14 "If I then, your Lord and Teacher, have washed your feet, you also ought to wash one another's feet."}

The above verse shows that Christ himself has served and therefore wishes all his followers to do likewise, and especially towards one another. Nee, puts it straight; "Service to God originates from God; it is man serving God through submission to his authority. The result is acceptance... Are we under the principle of service or we under the principle of strange fire?" 22 Service is an idea of God. If He is the object of service, then leaders must do it His way, to remain His servants. For true service to be done, leaders must have been submissive, for the two go hand in hand, to serve God acceptably is to be submissive to Him on His terms. Jesus encourages His disciples not only to know the act of service but go further to render that act of service, so they may be blessed. The best way He could teach them how to serve was to practice it right before them. This means leaders (servants) must demonstrate to those they lead the act of service and not only say it with their mouths. Likewise, people misunderstood Jesus, people would misconstrue the good intentions of leaders and this could lead to despair. But if leaders are serving their fellow men and women and doing it as unto the Lord, then the human response to their service would not get them discouraged in their act of service to them.

Christian service must therefore be under the direction of the Holy Spirit. Wiersbe describes the situation this way, "when the Holy Spirit does take over, there will be liberty, not bondage but cooperation, not a competition but to the glory of God, not praise to man. The world will see true Christianity, and through genuine service, sinners will come to know the savior. There is an old-fashioned word for this: revival." ${ }^{23}$ Service as Wiersbe puts it, must be directed by the Holy Spirit, this is the service that would bring blessings, and through it, the world would see the glory of God and true Christian service becoming meaningful.

\section{CONCLUSION}

Service to human beings and God as a style of leadership is good in itself and seems to be the way God expected humanity to live right from the beginning. In the design of the creator, servanthood and leadership seem like Siamese twins. The seeming distortions and problems that have emerged are therefore not part of the divine plan of God. It is

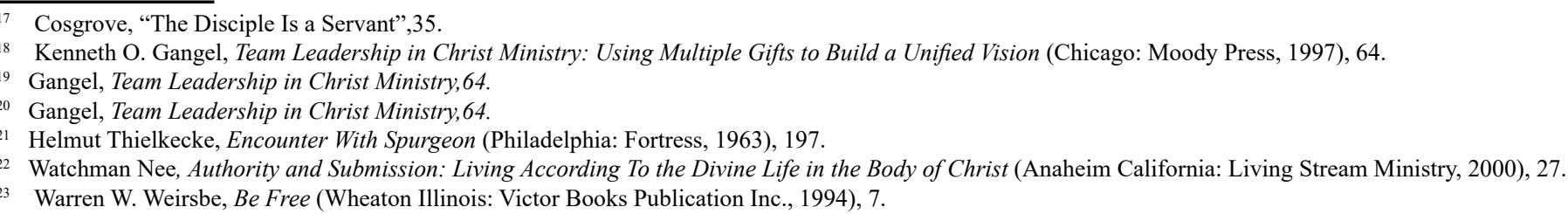


the responsibility of all, especially Christians to harness the potential of service for the common good of all and work assiduously to correct the distortions and problems associated with leadership. This analysis has shed some light on the theological significance of the issues on servanthood and its correlation with the feet washing for a better understanding of what service should be. Jesus loved his disciples to the end because he loved God and has experienced him, hence his preparedness to give and even give himself out for them completely. The servant-leader must understand that, humility and service borne out of love are prerequisites for Christian leadership and to be able to serve, this love must be present and propel servant leaders to serve by giving themselves to others, for service to man is service to God. To be able to serve at all is a demonstration of spiritual maturity, and the level of one's spirituality is directly related to his love for God and towards his fellow human beings.

\section{ABOUT AUTHOR}

Philip Quacoe-Takrama is a Tutor at the Sefwi-Wiawso College of Education, Department of Social Science, and a PhD Student at University of Cape Coast, Ghana.

\section{BIBLIOGRAPHY}

Barclay W., The Gospel of John Vol. 2: XIII-XXI. Edinburgh: The Saint Andrew Press, 1961.

Barrett C. K., Peake's Commentary on the Bible. London: Thomas Nelson Printers, 1967.

Bruce F.F. et al.,The New Bible Dictionary. London: Intervarsity Press, 1974.

Collins J. N., Diakonia: Reinterpreting the Ancient Sources. Oxford: Oxford University Press, 1990.

Cosgrove F., "The Disciple Is a Servant", In Discipleship Journal 30 (1985):35-38.

Hastings J., Dictionary of the Bible: Complete in One Volume. New York: Charles Scribner's Sons, 1952.

Hind J., The Heart and Soul of Effective Management. Wheaton Illinois: Victors Press, 1989.

Gangel K. O., Team Leadership in Christ Ministry: Using Multiple Gifts to Build a Unified Vision.Chicago: Moody Press, 1997.

Mott J.R., Revival Fire. London: Hodder and Stoughton, 1990.

Nee W., Authority and Submission: Living According to the Divine Life in the Body of Christ. Anaheim California: Living Stream Ministry, 2000.

Richard O. L \& Hoeldtke C. A., Theology of Church Leadership. Grand Rapids: Zondervan Press, 1980.

Sanders O. J., Spiritual Leadership: The Principle of Excellence for Every Believer. Chicago: Moody Press, 1994.

Thielkecke H., Encounter with Spurgeon. Philadelphia: Fortress, 1963.

Wiersbe W.W., Be Free. Wheaton Illinois: Victor Books Publication Inc., 1994. . Live like King: Living the Beatitudes Today. Chicago: Moody Press, 1980. 